\title{
Rebound Effect of Allowance for Corporate Equity on Debt Bias
}

Márcio Telles Portal

Luís Laureano

ISCTE - Instituto Universitário de Lisboa BRU-IUL (Unide-IUL)

Av. Forças Armadas 1649-126 Lisbon-Portugal http://bru-unide.iscte.pt/ 


\title{
Rebound Effect of Allowance for Corporate Equity on Debt Bias
}

\author{
Márcio Telles Portal ${ }^{a, 1}$, Luís Laureano ${ }^{\mathrm{b}}$ \\ ${ }^{a}$ UNISINOS Business School, Universidade do Vale do Rio dos Sinos (UNISINOS), Av Unisinos \\ 950, CEP 93.120-180, São Leopoldo, Rio Grande do Sul, Brazil \\ ${ }^{\mathrm{b}}$ Instituto Universitário de Lisboa (ISCTE-IUL), BRU-IUL, Lisboa, Portugal
}

\begin{abstract}
We analyse if the Brazilian Allowance for Corporate Equity (ACE-type system) reduces the debt tax bias. Specifically, we study if the continuous treatment effect of interest on equity negatively affects the level of financial leverage. We find that the tax policy implemented is similar to the deductible cash dividends and not to an ACE. The empirical implication is that the interest on equity treatment increases the debt tax bias, producing a rebound effect to what is expected for this policy on the risk-taking behaviour and corporate capital structure. This rebound effect is homogeneous in firms with different financial constraints status. There are evidences that shareholders influence the cash distribution policy, adjusting the later to their own tax preferences.
\end{abstract}

Keywords: capital structure; debt bias; dividend; dose-response function; financial constraints; taxation.

JEL classification: G32, G35, H20, H25

\section{Introduction}

The tax deductibility of interest expenses has been considered to be an historical accident (Schoenmaker \& Goodhart, 2010), with no legal or economic reasons for its existence as policy (Hemmelgarn \& Nicodeme, 2010; Warren Jr., 1974). The tax discrimination between debt and equity has been identified as a policy leading to harmful effects on the legal distinction between the two types of financing (Warren Jr., 1974), on how the firms choose their financing sources and on how much risk they bear (Hemmelgarn \& Nicodeme, 2010). To De Mooij (2011), the deductibility of debt has created a debt tax bias favouring the excessive use of leverage, which has been associated with a higher vulnerability of firms in the presence of credit crunches. When there is rationing in the supply of credit or equity, a tax distortion may favour firms with better

\footnotetext{
${ }^{1}$ Corresponding author. Tel.: +55 5181083305

E-mail addresses: mtportal@unisinos.br (M. T. Portal), luis.laureano@iscte.pt (L. Laureano)
} 
access to the credit market (Meza \& Webb, 1987). This discrimination may also be associated with avoidances strategies (tax minimization) by debt-shifting within the business group, by tax arbitrage between affiliates in countries with different marginal tax rates, or by using hybrid instruments (De Mooij \& Devereux, 2010; Hemmelgarn \& Nicodeme, 2010). In the same line, the debt tax shield can lead to a distortion on the efficient investment allocation, favouring projects that otherwise would not be followed without this benefit (Fatica, Hemmelgarn \& Nicodème, 2012).

The theoretical and empirical discussion regarding policies to correct or eliminate the debt tax bias is not new. However, recent evidence that the debt-equity tax distortion amplified the adverse effects of the recent financial crisis on firms (De Mooij, Keen \& Orihara, 2013; Hemmelgarn \& Nicodeme, 2010; IMF, 2009; Shackelford, Shaviro \& Slemrod, 2010; Shaviro, 2012) and also pervert the corporate policies on the capital and income flows due to the increasing business internationalization (De Mooij \& Devereux, 2010), have brought back this subject to light.

There are several policy options to reduce the debt tax bias by changing the corporate tax system. There are the more conventional ones, such as, reducing the corporate tax rate in order to decrease the debt tax shield, implementing thin capitalization rules, or limiting the deductibility of the interest expenses (Fatica, Hemmelgarn \& Nicodème, 2012). However, such measures increase the complexity of the tax system and their effectiveness is questionable (De Mooij \& Devereux, 2010). A more extreme measure would be to implement a system of Allowance for Corporate Equity (ACE).

Although several initiatives to address the debt bias have taken place on developed European countries, the emerging economies could potentially benefit more from these initiatives, since they face higher levels of leverage and less resilient financial systems (FSB Financial Stability Board, 2015). In this context, Brazil is known as being the only emerging country with experience implementing an ACE-type system. Meanwhile, given the specificities of the Brazilian system, one may question its effectiveness as a tool to reduce the debt tax bias. Thus, the main goal of this research is to empirical verify the real effects of this tax policy on the debt tax bias. The empirical strategies followed aim at surpassing the methodological limitations of previous studies while considering: the policy implementation as a continuous treatment; confounding factors; auto-selection bias and treatment endogeneity.

The results suggest that the specificities of the Brazilian system mischaracterize the system as an ACE-type, making it just a deductible tax system of cash distribution to shareholders. Indeed, the tests performed show that the Brazilian ACE-type system produces the opposite effect to the one expected from this type of system, that is, increases the debt tax bias (rebound effect) instead of reducing it. Additional tests also show that this rebound effect is not idiosyncratic to the financial constraint level of the firm. 
The present study contributes to the existing literature on tax policy, on capital structure and on cash distribution policies. At the tax level it contributes to a better understanding on how different ACE systems affect the effectiveness on reducing the debt tax bias, subject to institutional factors specific of emerging economies. Mainly, it clarifies that the Brazilian tax system cannot be considered an ACE-type system experiment. To the literature on capital structure and cash distribution, it allows for a better understanding on how the tax factor affects both policies simultaneously. This research also contributes to better understand how shareholders may influence the cash distribution policy, adjusting the later to their own tax preferences. The Brazilian case is the only one known that allows us to investigate the effect of dosage of the ACE policy. This study is the first to explore this opportunity and adequately address confounding factors.

This paper is structured as follows: in section 2, we present the main characteristics of the ACE systems and the specificities of the Brazilian ACE-type system, and also develop our working hypotheses; in section 3, we outline the empirical strategy; in section 4, we report the results and proceed with the discussion; and, in section 5, we make the final remarks.

\section{ACE system and hypotheses development}

\subsection{Brazilian ACE-Type System}

ACE is a variant of Allowance for Corporate Capital (ACC) first proposed by (Boadway $\&$ Bruce, 1984). The main idea behind ACC is to abolish the deductibility of the interest expenses and replace it by a notional risk-free return on the book value of the firm's capital. The ACE-type system, first introduced by the Capital Taxes Committee of the Institute for Fiscal Studies (Devereux \& Freeman, 1984; IFS Capital Taxes Group, 1991) differs from the ACC by still allowing the deductibility of the interest expenses, while adding the tax deductibility against corporate profits of a notional risk-free rate on equity. Both the ACC and the ACE systems assume the notional return as being risk free, since the tax advantage from its deductibility is taken for granted (Bond \& Devereux, 1995).

The Comprehensive Business Income Tax (CBIT) has been considered as an alternative to ACE system. CBIT system eliminates the deductibility of the interest expenses, and thus eliminates the debt tax bias, it leads to negative collateral effects by increasing the firm's cost of capital and by exacerbating the distortion on marginal investments. De Mooij \& Devereux (2010) consider the ACE system preferable to the CBIT system because of the following four favourable properties: first and foremost, it allows for the neutrality between debt and equity; second, it neutralizes the tax effect on marginal investment decisions; third, it avoids the distortion on investment induced by differences between economic and tax depreciation; and fourth, it lowers the firm's cost of capital. 
De Mooij \& Devereux (2010) use a general equilibrium model to simulate the implementation of both the ACE and CBIT systems in the European Community. Given the need to adjust the statutory corporate tax in order to compensate for the reduction on tax revenue on the ACE system, there is an increase in the effective average tax rate (EATR). A higher EATR decreases the internal funds and intensifies the international profit shifting and discrete location, which affect corporate investment decisions. These collateral effects of the ACE system make the CBIT system more efficient and welfare improving, at the country level, and also in the presence of capital-market imperfections (Hubbard, 1998). Meanwhile, the ACE system becomes more efficient than the CBIT system when implemented in a jointly manner through all the European Community. In addition to the experiences that have been made regarding the ACE system, this is also the preferred system by some of the proponents of fiscal policies to reduce the debt bias (IFS Capital Taxes Group, 1991; FSB Financial Stability Board, 2015).

Simulation models evaluating individual fiscal reforms using variants of the ACE system in Switzerland (Keuschnigg \& Dietz, 2007) and Germany (Radulescu \& Stimmelmayr, 2007) suggest a reduction on the cost of capital and an increase in the investment level. However, the results from real experiments implementing the ACE-type systems (e.g. in Austria, Belgium, Croatia and Italy) show no clear-cut evidence on the economic impact of these reforms (De Mooij $\&$ Devereux, 2010). This lack of evidence is mostly due to two factors: first, the implementation of the ACE system on these countries was part of a package of multiple reforms, making it hard to identify the impact of a specific reform; and second, the reforms did not include all the characteristics of the ACE system, thus being only an ACE-type system. The exception to both these factors was the implementation of the ACE system in Belgium, in 2006.

Brazil is the only emerging economy with an ACE system. The country implemented in 1996 a tax reform, Law 9.249/95 (Brasil, 1995), which has been classified as an ACE-type system (Klemm, 2007; IMF, 2009; De Mooij, 2012; ICC Commission on Taxation, 2012; Panier, González-Pérez \& Villanueva, 2013). However, and although sharing common goals, the Brazilian system diverges in fundamental properties from the other implemented systems and from the original proposal by IFS Capital Taxes Group (1991).

The Brazilian ACE-type system is characterized by three distinctive elements. First, it only allows for the tax deductibility of the notional interest, denominated as interest on equity (IOE), when this is paid out to the shareholders. The IOE is deducted when considering the corporate income tax (CIT). Brazilian CIT is $34 \%$ and includes an income tax rate of $25 \%$, Law $\mathrm{n}^{\circ}$ 9.249/1995 (Brasil, 1995), and a social contribution tax rate of 9\%, Law n $\mathrm{n}^{\circ}$.689-88 (Brasil, 1988). To determine the IOE we have to consider the amount of equity (E) minus the revaluation 
reserves (RR), both from the previous fiscal year, i.e. $\left(E_{t-1}-R R_{t-1}\right)$. The notional risk-free rate used is the Long-Term Interest Rate (LTIR) ${ }^{2}$ in $t-1$.

Second, the system includes eligibility criteria that limits the level of notional interest accepted as tax deductible. Eligible firms are those that cumulatively have in $t-1$ positive equity and also fulfil one of the following criteria: having positive earnings before interest and taxes (EBIT), or having positive retained earnings (RE). The IOE accepted for deductibility must not exceed $50 \%$ of the EBIT or $50 \%$ of the RE, the highest.

Third, there is a tax rate of $15 \%$ on the interest on equity, which is retained by the paying firm. Additionally, the personal income tax rate on the interest on equity received varies in accordance to the nature of the beneficial shareholder. When the shareholder is a physical entity or the government, the retained tax rate of $15 \%$ is definitive. Institutional investors and pension funds are exempt from income tax, Law 9.532/1997 art. 28 and 33 (Brasil, 1997), and thus compensation is allowed. When the shareholders are firms, these are taxed through the real income system and may be compensated for the retained tax rate of $15 \%$, but are subject to an income tax rate of $34 \%$ on the financial income from the interest on equity received (firms with an annual income lower than $\mathrm{R} \$ 240.000$ have a lower tax rate of $24 \%$ ). Additionally, when the shareholders are firms, these must pay for social purposes $1.65 \%$ and $7.6 \%$ on the interest on equity received, corresponding to the contribution to the Programa de Integração Social (Social Integration Program) and Contribuição para Financiamento da Seguridade Social (Contribution to Social Security Financing), respectively.

Overall, the tax savings ${ }^{3}$ for physical entities and government is $19 \%(34 \%-15 \%)$, to institutional investors and pension funds is $34 \%$ (34\%-0\%), e to legal entities it may be $-9.25 \%$ (34\%-15\%-34\%-9.25\%) or $0.75 \%$ (34\%-15\%-24\%-9.25\%), depending on the income level of the firm. Besides, in the case where the shareholders are firms, the disincentive increases as one uses corporate control structures of pyramidal form, due to the double taxation (or more, depending of the control-enhancing mechanism level adopted). So, depending on the legal form of the shareholder, one may find significant differences in the tax incentives, and thus on the propensity to be willing to receive the interest on equity. Boulton, Braga-Alves \& Shastri (2012) and Colombo \& Terra (2014) find evidence on Brazilian firms that the legal form of the controlling shareholders affect not only the propensity to pay, but also the amount of interest on equity paid. The authors point out the positive effect on the IOE paid when institutional investors, with a minimum stake in the firm of $5 \%$ of shares with voting rights, are present.

\footnotetext{
2 The term used in Brazil is Taxa de Juros de Longo Prazo (TJLP). The TJLP is determined by Conselho Monetário Nacional (CMN) and is used as the long term financing cost on the loans granted by the state banks for development.

${ }^{3}$ For numeric examples please see Boulton et al. (2012) and Colombo \& Terra (2014).
} 


\subsection{Hypotheses development}

Implementing an ACE system is expected to reduce the debt tax bias, which in turn should lead to a lower debt-to-equity ratio. That would happen because the firm would be using more internal or external equity instead of debt. In fact, Panier et al. (2013) find this expected result when analysing Belgium firms after the implementation of the ACE system in that country.

Meanwhile, the characteristic of the Brazilian ACE system, to only allow for the deductibility of the interest on equity paid out to shareholders, may have three important implications. First, firms need to cash out to obtain the deductibility, thus making the latter dependent on existing internal funds and directly competing with growth opportunities (Fazzari, Hubbard \& Petersen, 1988). In frictionless capital markets firms would have the necessary conditions to access the equity market and adjust their capital structure when needed (Modigliani $\&$ Miller, 1958). However, in the presence of markets imperfections, this adjustment may be slower or even impossible to follow (Almeida \& Campello, 2010).

Second, there is an effect derived from accounting mechanics on the debt-to-equity ratio. This is due to the fact that even if the deductibility of interest on equity leads to a reduction on the debt tax bias, the cash out needed lowers the retained earnings and, consequently, lowers the equity level. Thus, the tax incentives to use equity instead of debt, in the presence of imperfect capital markets, may not be sufficient to compensate the reduction on internal equity.

Third, when internal funds become insufficient, firms may access the debt market to obtain the necessary funds to pay out interest on equity to shareholders. If this is the case, firms may benefit twice from the allowed deductibility, one from debt and another from interest on equity tax shield. Thus, we may observe a multiplying effect of the tax benefit. Additionally, the simulations performed by Almeida \& Paes (2013) suggest that the IOE in Brazil, despite reducing the cost of new equity, is not sufficient to compensate the tax benefit of debt financing.

Considering the three stated implications from the specificities of the Brazilian ACE-type system, we expect the existence of interest on equity to intensify the debt tax bias, instead of reducing it. The first research hypothesis is thus the following:

H1: The interest on equity positively affects the preference for debt financing instead of equity.

Firms may become financial constrained in the presence of capital markets imperfections (Hubbard, 1998; Almeida, Campello \& Weisbach, 2004; Crisóstomo, López-Iturriaga \& Vallelado González, 2014). Financially constrained firms may have difficulty in accessing the debt market, making internal and external funds not fully replaceable (Almeida \& Campello, 2010). Since internal funds are relatively less costly (Myers \& Majluf, 1984; Fazzari et al., 1988), 
this may lead to a preference for cash holdings instead of cash distribution to shareholders (Vogt, 1994; Hubbard, 1998; Almeida et al., 2004; Arslan, Florackis \& Ozkan, 2006). This behaviour is expected to be more severe in countries with weak investor protection, bank-oriented financial system and low level of development, similar to Brazil's (Khurana, Martin \& Pereira, 2009). Although the low use of tax benefits has been associated with conservative financial policies (Graham, 2000), recent evidence shows that when all tax shields and distress costs are accordingly considered, firms produce tax-efficient capital structures (Blouin, Core \& Guay, 2010). Additionally, simulations show that in Brazil the tax distortion is amplified when the access to less costly financing sources increases (Almeida \& Paes, 2013), condition favourable to financially unconstrained firms.

Therefore, the effect of interest on equity may be different in firms subject to different levels of financial constraints, with different financing costs and accessibility to external funds. The second research hypothesis is thus the following:

H2: The effect of interest on equity on the preference for debt instead of equity is higher in financially unconstrained firms.

\section{Data and Methodology}

\subsection{Data}

The initial sample included all non-financial firms listed on São Paulo's Stock Exchange (BM\&FBovespa) between 2000 and 20094. The financial statements were obtained from the Economática ${ }^{\circledR}$ database, while the information regarding ownership structure and American Depositary Receipt (ADR) was collected from the annual reports disclosed by the Comissão de Valores Mobiliários $(\mathrm{CVM})^{5}$. The list of quoted firms in three high-governance listings (Novo Mercado, Level I and Level II) was gathered from the BM\&FBovespa's ${ }^{6}$ website.

In order to reduce potential bias we applied the following restrictions: a) to exclude firms that have been involved in some sort of M\&A, all firm-year observations with an assets annual growth or sales growth higher than 100\% were eliminated (Acharya, Almeida \& Campello, 2007); b) to minimize existing measurement errors on the market-to-book variable, all firm-year observations with a value higher than 10 were eliminated; c) all firm-year observations that did not fulfil the requirements for the tax deductibility of interest on equity were excluded. This

\footnotetext{
4 The Brazil, from 1994 to 2000, experienced a major inflation control program, Real Plan in 1994, and financial crises in emerging markets in Asia, Russia and a domestic currency crisis. Therefore, these confounding factors can distort the purpose of assessing ACE implanting in Brazil, which prevents a reliable ex-ante vs. ex-post analysis.

${ }^{5}$ http://www.cvm.gov.br/ingl/indexing.asp.

${ }^{6} \mathrm{http}: / /$ www.bmfbovespa.com.br/en-us/markets/equities/companies/corporategovernance.aspx?Idioma=en-us.
} 
includes firm-year observations with negative Equity, and that cumulatively have negative Earnings Before Interest and Taxes and negative Retained Earnings; d) all continuous variables were winsorized at the top and bottom $2.5 \%$ level to avoid the effect of potential outliers.

\subsection{Empirical Strategy}

Implementing the ACE-type system is the remedy used for the treatment of the debt tax bias. The first stage of the empirical strategy addresses the first hypothesis (H1) in which the payment of interest on equity is expected to intensify the debt tax bias, and where this effect increases with higher payment levels. In order to do so, we look at the causal effect of the treatment variable interest on equity on an outcome representing the debt tax bias. In this research the outcome variable is proxied by two measures of financial leverage: the Financial debt-toassets ratio and the financial debt-to-capital ratio. Although the financial debt-to-capital ratio is more suitable, because it only considers the two deductible financing sources (Welch, 2011), we keep the Financial debt-to-assets ratio to allow the comparability with previous studies (Klemm, 2007; Ness Junior \& Zani, 2001; Zani, Leites, Macagnan, \& Portal, 2014) ${ }^{7}$, where this variable was used for similar purposes.

The first test involves a model estimation (see Equation 1), using ordinary least squares (OLS), where the dependent variable is leverage and the main predictor is interest on equity (IOE). As previously stated leverage is proxied by two different measures: the Financial debt-to-assets ratio and the financial debt-to-capital ratio. The variable IOE is defined as the ratio between interest on equity and total assets. Indicative of a reduction on the debt tax bias, we expect the coefficient of IOE to be negative and statistically significant. Following the existing literature on capital structure (Booth, Aivazian, \& Demirguc-kunt, 2001; Frank \& Goyal, 2009; Graham \& Leary, 2011; Harris \& Raviv, 1991) we include additional control variables in our model. The level of cash flow is measured by the ratio of cash flow-to-assets (Cash flow). CAPEX is the ratio of capital expenditures-to-assets while the level of cash holdings is measured as the ratio of cash holdings-to-assets (Cash holdings). We define firm size as the natural logarithm of assets (Size). To proxy for investment opportunities we use the market-to-book ratio of assets (Market-tobook). To control for differences between industries, and following (Frank \& Goyal, 2009), we include industry dummies according to the NAICS level 1 industrial classification system. Given the specific purpose of the present study, we include a control variable for the tax shield (Tax shield) in order to control for capital tax shields associated to the deductibility of interest expenses and interest on equity, but also to control for the non-capital tax shields, such as depreciation expenses and investment tax credit. Following Carvalhal \& Leal, 2013 and Costa, Paz \& Funchal

\footnotetext{
${ }^{7}$ Klemm (2007) used financial debt-to-equity, while Zani et al., (2014) used total debt-to-assets, which is a measure with more error for considering other non-deductible sources of financing (e.g., trade credit).
} 
(2008), we use a dummy for ADR firms (Financial unconstraint) in order to control for the different access levels to the capital markets. All variables definitions are presented in Appendix 1 .

$$
\begin{aligned}
\text { Leverage }_{i, t}= & \alpha_{0}+\beta_{1} \text { IOE }_{i, t}+\beta_{2} \text { Cash flow }_{i, t}+\beta_{3} \text { CAPEX }_{i, t}+\beta_{4} \text { Size }_{i, t}+\beta_{5} \text { Market-to-book }_{i, t}+ \\
& \beta_{6} \text { Tax shield }_{i, t}+\beta_{7} \text { Financial unconstraint }_{i, t}+\beta_{8} \text { Cash holdings }_{i, t}+ \\
& \sum_{\text {ind }} \text { Industry }_{\text {ind }}+\sum_{t} \text { Year }_{t}+\varepsilon_{i, t}
\end{aligned}
$$

Given the characteristics of the Brazilian ACE-type system presented in Section 2, we know that the interest on equity treatment is not random. In fact, firms must comply with a set of eligibility criteria, have available internal funds or access to the external funds market, and also take into consideration the tax preferences of their shareholders. These may induce a potential problem of selection bias/self-selection bias, which violates the unconfoundedness assumption (Rosenbaum \& Rubin, 1983). Therefore, estimation through OLS is unappropriated because treated and non-treated firms may respond differently to specific observables and unobservable confounders, as well as to treatment intensity $(t)$. Given the specific characteristics of the study, we apply continuous treatment effects estimated using a dose-response function (DRF) on endogenous and exogenous treatment, as proposed by Hirano \& Imbens (2004) and implemented by Cerulli (2014). The DRF enable us to observe the effect of a continuous treatment - interest on equity - while the treatment reacts to observable (exogenous treatment) or to unobservable (endogenous treatment) confounders, and also enable us to evaluate the effect not only of the payment decision $(w)$ of IOE, but also the effect of the its level of payment $(t)$ on the debt tax bias. The implementation by Cerulli (2014) is adequate for the following reasons: it does not assume full normality, adjusting well to the case where there are several firm-year observation with zero-level of treatment; firms may react differently to observables confounders; and it allows for the inclusion of endogenous treatment on unobservables confounders.

In this context, we performed a second test of the first hypothesis (H1), estimating a DRF under exogenous treatment, where the unconfoundness condition (or conditional mean independence) of a set of exogenous variables restores the condition of randomness. This allows us to estimate the average treatment effect $\left(\mathrm{ATE}_{(\mathrm{t})}\right)$ directly from the regression obtained through DRF-OLS (Cerulli, 2014; Hirano \& Imbens, 2004). The outcome equation (Equation 2) is specified as follows:

$$
\begin{aligned}
& \text { Leverage }_{i, t}=\alpha_{0}+\beta_{1} \text { IOE }_{i, t}+\beta_{2} \text { Cash flow }_{i, t}+\beta_{3} \text { CAPEX }_{i, t}+\beta_{4} \text { Size }_{i, t}+ \\
& \beta_{5} \text { Market-to-book }_{i, t}+\beta_{6} \text { Tax shield }_{i, t}+\beta_{7} \text { Financial unconstraint }_{i, t_{i, t}}+\beta_{8} \text { Cash holdings }_{i, t}+ \\
& a T w_{i, t}+b T^{2} w_{i, t}+c T^{3} w_{i, t}+\sum_{\text {ind }} \text { industry }_{\text {ind }}+\sum_{t} \text { year }{ }_{t}+\varepsilon_{i, t}
\end{aligned}
$$

Our variable of interest is IOE. The goal is to get the average treatment effect (ATE) on a given dosage $(t)$ of IOE on the Leverage The $\operatorname{ATE}_{(t)}$ is obtained by the weighted average of each 
different propensity score estimated for a given dose of treatment $(t)$. The identification of ATE e DRF is obtained with three polynomial factors of the DRF, $a T w_{i, t}, b T^{2} w_{i, t}$ and $c T^{3} w_{i, t}$. We include the same control variables used in Equation 1.

Our variable of interest is IOE, estimated on equations 3 and 4 . The goal is to get the average treatment effect (ATE) on a given dosage $(t)$ of IOE on the Leverage The $\operatorname{ATE}_{(t)}$ is obtained by the weighted average of each different propensity score estimated for a given dose of treatment $(t)$. We include the same control variables used in Equation 1.

The third test for our first hypothesis (H1) includes the estimation of a DRF under the endogenous treatment $w$ (and not $t$ ), where the selection-into-treatment is dependent on both observable and unobservable confounders. In this case, we need to use a type-2 tobit model with instrumental variables (IV) estimation in order to restore the consistency of the estimators. The estimation process involves the estimation of three models: (1) an outcome model where the outcome is defined through a measure of financial leverage, presented in Equation 2; (2) a selection model where the selection $w$ is defined as a dummy variable equal to payment $(w=1)$ and non-payment $(w=0)$ of interest on equity, presented in Equation 3; (3) a treatment level model, presented in Equation 4, with the dosage level $t$ being defined as a standardized variable taking values within the continuous range [0;100], so 0 corresponds to the minimum value, and 1 to the maximum level of interest on equity paid.

The estimation of the DRF for the endogenous treatment follows two steps. In the first step we jointly estimate Equations 3 and 4 using the Heckman two-step bivariate sample-selection model $^{8}$ (Heckman, 1979). Heckman's model involves two procedures: (1) estimation of a Probit model of $w$ on a set of selection and control variables. The variable $w$ is defined as 1 for treated firms and as 0 for non-treated firms; (2) OLS estimation of a treatment-level equation of $t$ on a vector of selection variables plus the Mill's ratio $(\lambda)$ obtained through the selection equation (Equation 3). In the second step we use the predicted values of $w$ and $t$, obtained in the first step, and also a vector of independent variables, to estimate an outcome equation (Equation 2) using a two stages least squares (DRF-2SLS).

The selection Equation 3 is specified as follows:

$$
\begin{aligned}
& W(I O E)_{i, t}= \alpha_{0}+\beta_{1} \text { Cash }_{\text {flow }}+,+\beta_{2} \text { CAPEX }_{i, t}+\beta_{3} \text { Size }_{i, t}+\beta_{4} \text { Market-to-book }_{i, t}+ \\
& \beta_{5} \text { Tax shield }_{i, t}+\beta_{6} \text { Financial unconstraint dummy }_{i, t}+\beta_{7} \text { Cash }_{\text {oldings }}+,+ \\
& \beta_{8} \text { Funds dummy }_{i, t}+\beta_{9} \text { Individual dummy }_{i, t}+\beta_{10} \text { Firm dummy }_{i, t}+ \\
& \beta_{11} \text { Dividends dummy }_{i, t}+\beta_{12} \text { Governance quality dummy }_{i, t}+\sum_{\text {ind }} \text { Industry }_{\text {ind }}+ \\
& \sum_{t} \text { Year }_{t}+\varepsilon_{i, t} \\
& \text { (Equation 3) }
\end{aligned}
$$

\footnotetext{
${ }^{8}$ Previous results using maximum-likelihood estimation were qualitatively similar.
} 
Where $\mathrm{W}(\mathrm{IOE})$ is defined for two firm groups: (i) non-treated firms with $\mathrm{W}(\mathrm{IOE})=0$, with a treatment level of $t=0$; and (ii) treated firms with $\mathrm{W}(\mathrm{IOE})=1$, with a treatment level of $t>0$. Although Miller \& Modigliani (1961) suggest that the cash distribution does not affect shareholders' wealth, there is large evidence of tax preferences by shareholders, where controlling shareholders (Brav, Graham, Harvey, \& Michaely, 2008; Chetty \& Saez, 2005; Korkeamaki, Liljeblom, \& Pasternack, 2010) and minority institutional investors (Desai \& Jin, 2011) may influence firms' decisions in order to accommodate their individual tax preferences. Additionally, Morck (2004) suggests that there is a negative relation between intercorporate dividend taxation and the formation of pyramidal control structures.

Given the previous evidence, the vector of selection variables that determines the liquid benefits of a firm being in condition $w=1$ or $w=0$ is supported on the different tax systems associated with the shareholders' legal form, on the quality of corporate governance, and on the alternative methods of cash distribution to shareholders. To proxy for these factors, we use the following variables: a dummy variable for a minority stake by institutional investors (Fund dummy); a dummy variable for the controlling firm (Firm dummy); a dummy variable for individual control (IND); a dummy variable for the list of quoted firms in three high-governance listings (Novo Mercado, Level I and Level II) in BM\&Bovespa (Governance quality dummy); and a dummy variable for the payment of cash dividends (Dividends dummy). The control variables used in Equation 1 are also included.

The treatment-level Equation 4 is specified as follows:

$$
\begin{aligned}
T(I O E)_{i, t}= & \alpha_{0}+\beta_{1} \text { Cash flow }_{i, t}+\beta_{2} \text { CAPEX }_{i, t}+\beta_{3} \text { Size }_{i, t}+\beta_{4} \text { Market-to-book }_{i, t}+ \\
& \beta_{5} \text { Tax shield }_{i, t}+\beta_{6} \text { Financial unconstraint dummy }_{i, t}+\beta_{7} \text { Cash holding }_{i, t}+ \\
& \beta_{8} \text { Deductible IOE }_{i, t}+\beta_{9} \text { Control rights }_{i, t}+\beta_{10} \text { Payout ratio }_{i, t}+\beta_{11} \lambda_{i, t}+ \\
& \sum_{\text {ind }} \text { Industry }_{\text {ind }}+\sum_{t} \text { Year }_{t}+\varepsilon_{i, t}
\end{aligned}
$$

Where T(IOE) is defined as the dosage $(t)$ of interest on equity divided by the total assets of firm $i$ in year $t$. The variable $\mathrm{T}(\mathrm{IOE})$ is normalized in order to only vary between 0 (inexistence of treatment) and 100 (maximum level of observed treatment). We include the same control variables of Equations 1 and 2. Besides the control variables, we also consider three variables that contribute to the selection of the treatment level $(t)$ : the maximum level of deductible interest on equity legally accepted (Deductible IOE), stated in (Brasil, 1995); percentage of shares with voting right held by the controlling shareholder (Control rights); and the payout ratio of the firm (Payout ratio), used as an alternative mean of cash distribution to shareholders. The operational definition of all variables are presented in the Appendix.

The test of our second hypothesis (H2) involves reproducing the second and third tests from Hypothesis 1, which are the estimation of DRF-OLS and DRF-IV. The goal is to verify if the effect of the IOE treatment on the debt tax bias is heterogeneous, dependent on the financial 
constraint status of the firm. This heterogeneous effect is determined by an idiosyncratic average treatment effect $\left[\mathrm{ATE}_{(\mathrm{x})}\right]$ on observables variables. A common measure used to classify Brazilian firms according to their financial constraint status is a firm's ability to issue ADR (Costa et al., 2008; Portal, Zan, \& Silva, 2012). Therefore, we use a dummy variable (Financial unconstraint dummy) to indicate a financially unconstrained firm (with ADR, dummy equal to 1) or financially constrained firm (without ADR, dummy equal to 0). We proceed with the estimation of the selection equation (Equation 3) and the treatment level equation (Equation 4), and then of the outcome equation (Equation 5) with the following specification:

$$
\begin{aligned}
& \text { Leverage }_{i, t}= \alpha_{0}+\beta_{1} \text { IOE }_{i, t}+\beta_{2}\left(\text { IOE }_{i, t} \times \text { Financial unconstraint dummy }_{i, t}\right)+\beta_{3} \text { Cash flow }_{i, t}+ \\
& \beta_{4} \text { CAPEX }_{i, t}+\beta_{5} \text { Size }_{i, t}+\beta_{6} \text { Market-to-book }_{i, t}+\beta_{7} \text { Tax shield }_{i, t}+ \\
& \beta_{8} \text { Financial unconstraint dummy }_{i, t}+\beta_{9} \text { Cash holdings }_{i, t}+\sum_{\text {ind }} \text { Industry }_{\text {ind }}+ \\
& \sum_{t} \text { Year }_{t}+\varepsilon_{i, t} \\
& \text { (Equation 5 }
\end{aligned}
$$

The variable of interest is the interaction between IOE and the Financial unconstraint dummy and we expect its coefficient to be positive and statistically significant. The remaining properties of Equation 5 are the same of Equation 2.

\section{Empirical results and discussion}

Table 1 reports the descriptive statistics of all the variables of interest. We can observe that capital financing (equity and financial debt) represents, on average, $38 \%$ of firms' total assets, and that the financial debt constitutes $50 \%$ of the capital financing. The payment of interest on equity represents, on average, $0.5 \%$ the firms' total assets, while the maximum deductible value is, on average, $4.23 \%$ of total assets. Considering cash flow and cash holdings, these represent on average $9.15 \%$ and $10.27 \%$ of total assets, respectively. Firms seem to be very conservative when considering the potential tax benefit they could get from the payment of interest on equity. Interest on equity only represents $15.26 \%$ of the cash distribution to shareholders (IOE + cash dividends). Looking at the profile of the firm's shareholders, institutional investors are present in $13 \%$ of the firms, while 55\% have pyramidal control structures. Ownership by firms and family is present in about $33 \%$ and $27 \%$ of firms, respectively. About $74 \%$ of all firm-year observations include the payment of dividends, but only about $22 \%$ include the payment of IOE.

Table 1: Descriptive Statistics.

\begin{tabular}{lrrrr}
\hline & \multicolumn{1}{c}{ Mean } & \multicolumn{1}{c}{ Std. Dev. } & \multicolumn{1}{c}{ Min. } & \multicolumn{1}{c}{ Max. } \\
\hline Financial debt-to-assets & 0.3833 & 0.2335 & 0 & 0.8481 \\
Financial debt-to-capital & 1.0093 & 1.2045 & 0 & 5.5866 \\
IOE & 0.0047 & 0.0109 & 0 & 0.0424 \\
IOE normalized & 11.1713 & 25.6862 & 0 & 100 \\
CAPEX & 0.0686 & 0.0586 & -0.0087 & 0.239
\end{tabular}


Table 1 (continued): Descriptive Statistics.

\begin{tabular}{lrrrr}
\hline & Mean & Std. Dev. & Min. & Max. \\
\hline Cash flow & 0.0915 & 0.0745 & -0.1093 & 0.2674 \\
Cash holdings & 0.1027 & 0.1056 & 0.0009 & 0.4078 \\
ControlVoting rights & 67.3331 & 28.3347 & 0 & 100 \\
Deductible IOE & 0.0423 & 0.0299 & 0 & 0.1227 \\
Dividend & 0.0261 & 0.0355 & 0 & 0.1652 \\
Dividend dummy & 0.7441 & 0.4364 & 0 & 1 \\
Dividend normalized & 15.8216 & 21.5228 & 0 & 100 \\
Financial unconstraint dummy & 0.119 & 0.3239 & 0 & 1 \\
Firm dummy & 0.3291 & 0.47 & 0 & 1 \\
Funds dummy & 0.1265 & 0.3326 & 0 & 1 \\
Governance quality dummy & 0.2589 & 0.4381 & 0 & 1 \\
Individual dummy & 0.2673 & 0.4426 & 0 & 1 \\
IOE dummy & 0.2207 & 0.4148 & 0 & 1 \\
Market-to-book & 1.2169 & 0.5643 & 0.5223 & 3.1599 \\
Payout ratio & 0.1939 & 0.2921 & -0.4252 & 1.1304 \\
Pyramid control dummy & 0.5551 & 0.497 & 0 & 1 \\
Size & 14.3839 & 1.6683 & 9.7936 & 20.2605 \\
Tax shield & 0.0291 & 0.2131 & -1.1048 & 0.3644 \\
\hline
\end{tabular}

Table 2 reports the results obtained from the OLS estimation of Equation 1. The model includes industry and year fixed effects, and robust standard errors clustered at the firm level. The results indicate a negative effect of the IOE on both measures of leverage, suggesting that the treatment IOE lowers the debt tax bias. Overall, the control variables show statistical significance and sign in accordance with the existing literature on capital structure. These results are in line with those found by Zani et al. (2014). However, as discussed in Section 2, OLS estimation becomes inconsistent when the unconfoundedness assumption is violated. To re-establish the condition of unconfounded treatment assignment, and assuming an exogenous treatment, we estimate an OLS dose response function (DRF-OLS).

Table 2: The effect of IOE on the Debt Tax Bias using OLS.

\begin{tabular}{lrr}
\hline & $\begin{array}{c}\text { Financial } \\
\text { debt-to-assets }\end{array}$ & $\begin{array}{c}\text { Financial } \\
\text { debt-to-capital }\end{array}$ \\
\hline IOE & $-1.6664 * * *$ & $-2.7000^{* * *}$ \\
& $(-3.59)$ & $(-4.15)$ \\
Cash flow & $-0.6676^{* * *}$ & $-1.1078^{* * *}$ \\
& $(-7.57)$ & $(-8.81)$ \\
Cash holdings & $0.1363 *$ & 0.0626 \\
& $(1.80)$ & $(0.60)$ \\
Size & $0.0239 * * *$ & $0.0307 * * *$ \\
& $(3.43)$ & $(3.06)$ \\
Market-to-book & $0.0104 *$ & $0.0168 *$ \\
& $(1.69)$ & $(1.84)$ \\
Tax shield & $0.1332 * * *$ & $0.1896 * * *$ \\
Financial unconstraint dummy & $(3.05)$ & $(3.05)$ \\
& -0.0071 & -0.0282 \\
& $(-0.29)$ & $(-0.82)$
\end{tabular}


Table 2 (continued): The effect of IOE on the Debt Tax Bias using OLS.

\begin{tabular}{lrr}
\hline & $\begin{array}{r}\text { Financial } \\
\text { debt-to-assets }\end{array}$ & $\begin{array}{r}\text { Financial } \\
\text { debt-to-capital }\end{array}$ \\
\hline CAPEX & $0.5079 * * *$ & $0.4841^{* * *}$ \\
& $(5.01)$ & $(3.53)$ \\
Intercept & -0.1307 & -0.0883 \\
& $(-0.99)$ & $(-0.51)$ \\
Industry dummies & Yes & Yes \\
Year dummies & Yes & Yes \\
$R^{2}$ & 0.2496 & 0.2585 \\
Number of observations & 1877 & 1877 \\
Clusters in firm & 358 & 358 \\
\hline Note: $* * *$ and $* * *$ indicate statistical significance at the $10 \%, 5 \%$ and $1 \%$ \\
level, respectively. Robust t-statistics adjusted for firm-level clustering are \\
presented in parentheses.
\end{tabular}

Table 3 reports the results of the tests obtained through the DRF-OLS estimation for both proxies of financial leverage as the outcome variables. The results show that when the condition of unconfoundedness on specific observables is reintroduced, there is a positive and statistically significant effect of the treatment IOE on the Financial debt-to-capital measure. Conversely, the effect of the IOE is not statistically significant when the proxy Financial debt-to-assets is considered. As previously stated, as a proxy for the debt tax bias this ratio shows measurement deficiencies (Welch, 2011), and is only included in this study for comparison purposes with previous literature. Thus, we cannot reject our first hypothesis (H1) that the treatment by IOE tends to increase the debt tax bias instead of reducing it.

The test for our second hypothesis (H2) includes the interaction between the IOE treatment and the financial constrained status, proxied by the Financial unconstraint dummy variable. The results of this interaction, presented in Table 3 for the DRF-OLS estimation, show an inexistent effect of the treatment IOE on the debt tax bias when the financial constraint status of the firm is accounted for. The coefficient of the variable Financial debt-to-assets is negative, while positive for the Financial debt-to-capital variable. In both instances the coefficient is not statistically significant.

Table 3 also reports the estimation results for the control variables. These results are in line with the existing literature not only in the expected sign, but also regarding the statistical significance. We can observe that the three polynomial factors from the DRF show statistical significance. 
Table 3: The effect of IOE on the Debt Tax Bias using DRF-OLS.

\begin{tabular}{|c|c|c|c|c|}
\hline & $\begin{array}{c}\text { Financial } \\
\text { debt-to-assets }\end{array}$ & $\begin{array}{c}\text { Financial } \\
\text { debt-to-assets }\end{array}$ & $\begin{array}{c}\text { Financial } \\
\text { debt-to-capital }\end{array}$ & $\begin{array}{c}\text { Financial } \\
\text { debt-to-capital }\end{array}$ \\
\hline \multirow[t]{2}{*}{ IOE } & -0.0073 & -0.0068 & $0.0595 * *$ & $0.0590^{* *}$ \\
\hline & $(0.43)$ & $(-0.40)$ & $(2.31)$ & $(2.29)$ \\
\hline \multirow[t]{2}{*}{ IOE $\times$ Financial unconstraint dummy } & & -0.0159 & & 0.0150 \\
\hline & & $(-0.87)$ & & $(0.62)$ \\
\hline \multirow[t]{2}{*}{ Cash flow } & $-0.6715 * * *$ & $-0.6720 * * *$ & $-1.1054 * * *$ & $-1.1049 * * *$ \\
\hline & $(-11.39)$ & $(-11.38)$ & $(-13.15)$ & $(-13.14)$ \\
\hline \multirow[t]{2}{*}{ Cash holdings } & $0.1371 * * *$ & $0.1370 * * *$ & 0.0606 & 0.0607 \\
\hline & $(3.57)$ & $(3.57)$ & $(1.16)$ & $(1.17)$ \\
\hline \multirow[t]{2}{*}{ Size } & $0.0239 * * *$ & $0.0239 * * *$ & $0.0305^{* * *}$ & $0.0306 * * *$ \\
\hline & $(7.98)$ & $(7.97)$ & $(6.87)$ & $(6.87)$ \\
\hline \multirow[t]{2}{*}{ Market-to-book } & $0.0100 *$ & $0.0100 *$ & $0.0171 * *$ & $0.0171 * *$ \\
\hline & $(1.73)$ & $(1.72)$ & $(2.06)$ & $(2.07)$ \\
\hline \multirow[t]{2}{*}{ Tax shield } & $0.1325 * * *$ & $0.1325 * * *$ & $0.1876^{* * *}$ & $0.1876 * * *$ \\
\hline & (5.09) & $(5.09)$ & $(5.42)$ & $(5.42)$ \\
\hline \multirow[t]{2}{*}{ Financial unconstraint dummy } & -0.0075 & -0.0159 & $-0.0285^{*}$ & $-0.0331 *$ \\
\hline & $(-0.69)$ & $(-0.87)$ & $(-1.90)$ & $(-1.89)$ \\
\hline \multirow[t]{2}{*}{ CAPEX } & $0.5083 * * *$ & $0.5067 * * *$ & $0.4926 * * *$ & $0.4941 * * *$ \\
\hline & $(7.42)$ & $(7.38)$ & $(5.29)$ & $(5.31)$ \\
\hline \multirow[t]{2}{*}{$\mathrm{Tw}$} & $-0.0043 * *$ & $-0.0043 * *$ & $-0.0122 * * *$ & $-0.0122 * * *$ \\
\hline & $(-2.48)$ & $(-2.49)$ & $(-4.71)$ & $(-4.71)$ \\
\hline \multirow[t]{2}{*}{$\mathrm{T}^{2} \mathrm{w}$} & $0.0001^{* * *}$ & $0.0001 * * *$ & $0.0002 * * *$ & $0.0002 * * *$ \\
\hline & $(2.92)$ & $(2.93)$ & $(4.66)$ & $(4.65)$ \\
\hline \multirow[t]{2}{*}{$\mathrm{T}^{3} \mathrm{~W}$} & $-0.0000^{* * * *}$ & $-0.0000 * * *$ & $-0.0000 * * *$ & $-0.0000 * * *$ \\
\hline & $(-3.31)$ & $(-3.33)$ & $(-4.80)$ & $(-4.79)$ \\
\hline \multirow[t]{2}{*}{ Intercept } & $-0.1314^{*}$ & $-0.1308 *$ & -0.0958 & -0.0964 \\
\hline & $(-1.75)$ & $(-1.74)$ & $(-0.96)$ & $(-0.97)$ \\
\hline Industry dummies & Yes & Yes & Yes & Yes \\
\hline Year dummies & Yes & Yes & Yes & Yes \\
\hline$R^{2}$ & 0.2540 & 0.2542 & 0.2646 & 0.2647 \\
\hline Number of observations & 1877 & 1877 & 1877 & 1877 \\
\hline Clusters in firm & 358 & 358 & 358 & 358 \\
\hline
\end{tabular}

Table 4 reports the estimation results of the DRF-2SLS method on the effect of IOE on the debt tax bias, considering treatment endogeneity. The order of the results presented is as follows: estimation for the selection model (Equation 4); treatment level model (Equation 5) and outcome model (Equation 2). The selection and treatment level models are the same for all the outcome models (Financial debt-to-assets ratio and Financial debt-to-capital ratio).

The results from the selection model show that the variables Cash flow, Financial unconstraint dummy, Funds dummy and Dividend dummy (Size, Firm dummy and Pyramidal control dummy) are positively (negatively) related to higher propensity to pay IOE, with the corresponding coefficients presenting statistical significance. These results suggest that firms with higher cash flows and financially unconstrained tend to have higher payment of interest on 
equity. The ownership structure shows the expected effect on the propensity to pay IOE. Investment funds have more tax benefits with the IOE, and thus positively influence its payment. Since pyramidal ownership structures and firms shareholders have less tax benefits, or even additional costs with IOE, they tend to negatively influence its payment

The results from the treatment level model indicate that the level of payment of IOE is increasing (decreasing) with higher cash flow, growth opportunities, tax shield, maximum deductible amount of IOE and payment ratio (higher cash holdings, size, CAPEX and controller shareholder voting rights). These results are in line with what was expected from estimating the level of payment of IOE, since the latter should be positively related to the maximum deductible amount, to the tax shield and to cash flow. Given that cash holdings and CAPEX concur with the cash distribution to shareholders, it is reasonable to accept the negative relation verified with the payment level of IOE. The positive coefficient on the decision to pay dividends, on the selection model, and on the payout ratio, on the treatment level model, suggest that the two ways of cash distribution to shareholders (cash dividends and interest on equity) should be treated more as complements than substitutes. The three polynomial factors from the DRF systematically present statistical significance. The Lambda, a measure of the level of selectivity effect, obtained from the selection and treatment level models, is statistically significant and denotes the existence of selection problems on the treatment by IOE, and thus we should consider the treatment of IOE on the debt tax bias as being endogenous. The outcome models show a positive effect of IOE on both measures of financial leverage. Therefore, from either one of the DRF-OLS or DRF-2SLS estimations, we cannot reject Hypothesis 1 (H1) that the continuous treatment by IOE increases the debt tax bias instead of decreasing it. The control variables and the three polynomial factors on the outcome models of the DRF-2SLS estimation show the same signs and statistically significance of those obtained through the DRF-OLS estimation.

Table 4 also reports the estimation of the effect of the heterogeneous financial constraint status over the treatment IOE on the debt tax bias, when the treatment is endogenous. The results show that for both the Financial debt-to-assets and Financial debt-to-capital ratios, the estimated coefficients were positive but not statistically significant. Therefore, we cannot accept Hypothesis 2 (H2) that the rebound effect of the IOE on the debt tax bias is more severe on financially unconstrained firms. The results reported may be influenced by the costs of adjusting the capital structure. If this is indeed the case, firms subject to less adjustment costs should respond more quickly and contemporaneously to treatment (Almeida \& Campello, 2010; Strebulaev, 2007). Empiricaly, we should observe a negative coefficient in the tests performed for the heterogeneous effect resulting from firms with different financial constrained status (reported in Tables 3 and 4). However, these coefficients are positive, while not statistically significant. Therefore, we may discard the hypothesis that the results were driven by the costs of adjustment of the financial structure. 
Table 4: The effect of IOE on the Debt Tax Bias using DRF-2SLS.

\begin{tabular}{|c|c|c|c|c|c|c|}
\hline & \multirow{2}{*}{$\begin{array}{l}\text { Selection } \\
\text { Model }\end{array}$} & \multirow{2}{*}{$\begin{array}{c}\text { Treatment } \\
\text { Level Model }\end{array}$} & \multicolumn{4}{|c|}{ Outcome Models } \\
\hline & & & $\begin{array}{c}\text { Financial } \\
\text { debt-to-assets }\end{array}$ & $\begin{array}{c}\text { Financial } \\
\text { debt-to-assets }\end{array}$ & $\begin{array}{c}\text { Financial } \\
\text { debt-to-capital }\end{array}$ & $\begin{array}{c}\text { Financial } \\
\text { debt-to-capital }\end{array}$ \\
\hline $\mathrm{IOE}$ & & & $\begin{array}{r}0.5853^{* * *} \\
(2.05)\end{array}$ & $\begin{array}{r}0.6052^{* *} * \\
(2.13)\end{array}$ & $\begin{array}{r}0.8774 * * \\
(2.23)\end{array}$ & $\begin{array}{r}0.9008 * * \\
(2.31)\end{array}$ \\
\hline $\begin{array}{l}\text { IOE } \times \text { Financial } \\
\text { unconstraint dummy }\end{array}$ & & & & $\begin{array}{r}0.0404 \\
(0.63)\end{array}$ & & $\begin{array}{r}0.0478 \\
(0.54)\end{array}$ \\
\hline Cash flow & $\begin{array}{r}4.1784 * * * \\
(6.78)\end{array}$ & $\begin{array}{r}221.8396 * * * \\
(7.96)\end{array}$ & $\begin{array}{r}-0.6554 * * * \\
(-6.60)\end{array}$ & $\begin{array}{r}-0.6447 * * * \\
(-6.40)\end{array}$ & $\begin{array}{r}-0.8609 * * * \\
(-6.31)\end{array}$ & $\begin{array}{r}-0.8518^{* * *} \\
(-6.13)\end{array}$ \\
\hline Cash holdings & $\begin{array}{r}-0.6095 \\
(-1.58)\end{array}$ & $\begin{array}{r}-41.39 * * * \\
(-3.20)\end{array}$ & $\begin{array}{r}0.1130^{* * *} \\
(2.50)\end{array}$ & $\begin{array}{r}0.1119^{* *} \\
(2.45)\end{array}$ & $\begin{array}{r}0.0168 \\
(0.27)\end{array}$ & $\begin{array}{r}0.0155 \\
(0.25)\end{array}$ \\
\hline Size & $\begin{array}{r}-0.0778 * * \\
(-2.53)\end{array}$ & $\begin{array}{r}-1.1336 \\
(-1.02)\end{array}$ & $\begin{array}{r}0.0232 * * * \\
(6.77)\end{array}$ & $\begin{array}{r}0.0232 * * * \\
(6.67)\end{array}$ & $\begin{array}{r}0.0278 * * * \\
(5.89)\end{array}$ & $\begin{array}{r}0.0277 * * * \\
(5.81)\end{array}$ \\
\hline Market-to-book & $\begin{array}{r}-0.0217 \\
(-0.34)\end{array}$ & $\begin{array}{r}5.1558 * * * \\
(2.61)\end{array}$ & $\begin{array}{r}0.0149 * \\
\quad(1.87)\end{array}$ & $\begin{array}{r}0.0153^{*} \\
(1 . .91)\end{array}$ & $\begin{array}{r}0.0261 * * \\
(2.37)\end{array}$ & $\begin{array}{r}0.0266^{* * *} \\
(2.40)\end{array}$ \\
\hline Tax shield & $\begin{array}{r}-0.2711 \\
(-1.08)\end{array}$ & $\begin{array}{r}26.3324^{*} \\
(1.89)\end{array}$ & $\begin{array}{r}0.1193 * * * \\
(5.40)\end{array}$ & $\begin{array}{r}0.1190 * * * \\
(5.33)\end{array}$ & $\begin{array}{r}0.1676^{* * * *} \\
(5.52)\end{array}$ & $\begin{array}{r}0.1672 * * * \\
(5.45)\end{array}$ \\
\hline $\begin{array}{l}\text { Financial unconstraint } \\
\text { dummy }\end{array}$ & $\begin{array}{r}0.2467 * * \\
(1.98)\end{array}$ & $\begin{array}{r}-4.5361 \\
(-1.09)\end{array}$ & $\begin{array}{r}-0.0108 \\
(-0.68)\end{array}$ & $\begin{array}{r}-0.0231 \\
(-0.93)\end{array}$ & $\begin{array}{r}-0.0223 \\
(-1.02)\end{array}$ & $\begin{array}{r}-0.0368 \\
(-1.08)\end{array}$ \\
\hline CAPEX & $\begin{array}{r}-0.1337 \\
(-0.19)\end{array}$ & $\begin{array}{r}-56.6696^{* * *} \\
(-2.33)\end{array}$ & $\begin{array}{r}0.5685^{* * * *} \\
(6.29)\end{array}$ & $\begin{array}{r}0.5737^{* * * *} \\
(6.28)\end{array}$ & $\begin{array}{r}0.5873 * * * \\
(4.73)\end{array}$ & $\begin{array}{r}0.5935 * * * \\
(4.73)\end{array}$ \\
\hline Funds dummy & $\begin{array}{r}0.3484 * * * \\
(3.41)\end{array}$ & & & & & \\
\hline $\begin{array}{l}\text { Pyramidal control } \\
\text { dummy }\end{array}$ & $\begin{array}{r}-0.1601 * * \\
(-2.11)\end{array}$ & & & & & \\
\hline Firm dummy & $\begin{array}{r}-0.1584^{*} \\
(-1.73)\end{array}$ & & & & & \\
\hline Individual dummy & $\begin{array}{r}-0.0969 \\
(-0.97)\end{array}$ & & & & & \\
\hline Dividend dummy & $\begin{array}{r}0.9639 * * * \\
(7.74)\end{array}$ & & & & & \\
\hline $\begin{array}{l}\text { Governance quality } \\
\text { dummy }\end{array}$ & $\begin{array}{r}-0.0661 \\
(-0.65)\end{array}$ & & & & & \\
\hline Deductible IOE & & $\begin{array}{r}260.5789 * * * \\
(4.84)\end{array}$ & & & & \\
\hline Control rights & & $\begin{array}{r}-0.1024 * * \\
(-2.39)\end{array}$ & & & & \\
\hline Payout ratio & & $\begin{array}{r}9.6960^{* * *} \\
(3.01)\end{array}$ & & & & \\
\hline Tw & & & $\begin{array}{r}-0.0693 * * \\
(-2.00)\end{array}$ & $\begin{array}{r}-0.0710 * * \\
(-2.03)\end{array}$ & $\begin{array}{r}-.0933^{*} \\
(-1.95)\end{array}$ & $\begin{array}{r}-0.0953 * * \\
(-1.98)\end{array}$ \\
\hline $\begin{array}{l}\mathrm{T}^{2} \mathrm{w} \\
\mathrm{T}^{3} \mathrm{w}\end{array}$ & & & $\begin{array}{r}0.0015^{*} \\
(1.94) \\
-0.0000^{*}\end{array}$ & $\begin{array}{r}0.0016^{* * *} \\
(1.96) \\
-0.0000^{*}\end{array}$ & $\begin{array}{r}0.0018^{*} \\
(1.66) \\
-0.0000\end{array}$ & $\begin{array}{r}0.0019^{*} \\
(1.68) \\
-0.0000\end{array}$ \\
\hline & & & $(-1.93)$ & $(-1.94)$ & $(-1.54)$ & $(-1.55)$ \\
\hline Intercept & $\begin{array}{r}-1.1162 * \\
(-1.95)\end{array}$ & $\begin{array}{r}63.0435^{* * * *} \\
(2.73)\end{array}$ & $\begin{array}{r}-0.3328 * * * \\
(2.87)\end{array}$ & $\begin{array}{r}-0.3345^{* * *} \\
(-2.85)\end{array}$ & $\begin{array}{r}-1.1162^{*} \\
(-1.95)\end{array}$ & $\begin{array}{r}-0.3537 * * \\
(-2.19)\end{array}$ \\
\hline Lambda & $\begin{array}{r}-9.3249^{*} \\
(-1.73)\end{array}$ & & & & & \\
\hline $\begin{array}{l}\text { Industry and Year } \\
\text { dummies }\end{array}$ & Yes & Yes & Yes & Yes & Yes & Yes \\
\hline $\mathrm{N}$ & 1850 & 1850 & 1850 & 1850 & 1850 & 1850 \\
\hline
\end{tabular}

Note: $* * *$ and $* * *$ indicate statistical significance at the $10 \%, 5 \%$ and $1 \%$ level, respectively. Robust $\mathrm{t}$-statistics adjusted for firm-level clustering are presented in parentheses. 
Additionally, the results found may be being driven by accounting mechanics and managerial inertia (Welch, 2004), and not necessarily by tax factors. To rule out this hypothesis, we perform an additional test using dividend payment as treatment, instead of interest on equity 9 . This robustness test is adequate since the payment of dividends is an alternative way of cash distribution to shareholders that follows the same payment mechanisms as interest on equity. If the results are in fact being driven by this accounting mechanics associated with managerial inertia, than it would be reasonable to expect similar results between both treatments, both in direction as in magnitude. The coefficients for the variable of interest - Dividend treatment - from the estimation of the robustness tests are reported in Table 5. The estimation was performed using OLS, DRF-OLS and DRF-2SLS, for both measures of financial leverage. The results show a negative effect, with non-systematic statistical significance, of the treatment dividend payment on the financial leverage of firms. Therefore, we can reject the possibility of the rebound effect of the treatment IOE on the debt tax bias being driven by accounting mechanisms and managerial inertia. Overall, the tax motive is reinforced.

Table 5: Robustness Test: Effect of dividend payment on financial leverage

\begin{tabular}{|c|c|c|c|c|c|c|}
\hline & \multicolumn{6}{|c|}{ Outcome Models } \\
\hline & \multicolumn{3}{|c|}{ Financial debt-to-assets } & \multicolumn{3}{|c|}{ Financial debt-to-capital } \\
\hline & OLS & DRF-OLS & DRF-2SLS & OLS & DRF-OLS & DRF-2SLS \\
\hline \multirow[t]{2}{*}{ Dividend } & -0.0230 & $-0.0222 * *$ & -0.0541 & $-0.0818 * * *$ & $-0.0787 * * *$ & -0.1080 \\
\hline & $(-1.55)$ & $(-2.22)$ & $(-1.20)$ & $(-3.84)$ & $(-5.39)$ & $(-1.60)$ \\
\hline Control variables & Yes & Yes & Yes & Yes & Yes & Yes \\
\hline Industry dummies & Yes & Yes & Yes & Yes & Yes & Yes \\
\hline Year dummies & Yes & Yes & Yes & Yes & Yes & Yes \\
\hline Number of observations & 1877 & 1850 & 1850 & 1880 & 1850 & 1850 \\
\hline
\end{tabular}

\section{Conclusions}

Our results suggest that the Allowance for Corporate Equity (ACE) system implemented in Brazil leads to an increase on the debt tax bias. This is contrary to what is expected from this type of tax policy. It also goes against the existing literature where Brazil has been referenced as an example of an emerging country using the ACE system as a way to mitigate the debt tax bias. The results found are not heterogeneous regarding the firm's ability to access the external capital market. The tests are robust to different measures of financial leverage, and to the possibility that they are being driven by costs of adjusting the capital structure or accounting mechanisms.

\footnotetext{
${ }^{9}$ In the selection model the variable dividend payer is replaced by IOE payer, while in the treatment level model the variable payout ratio is replaced by IOE/assets.
} 
The empirical results suggest that the Brazilian ACE system is flawed, mainly because of two factors. The first is the fact of being required to distribution cash to shareholders for the tax deductibility. In this case, the ACE incentives do not compensate for the reduction in equity due to cash distribution. The second is due to the existence of tax benefits heterogeneous among shareholders firms, which favors the controlling shareholders which adjust the cash distribution according to their tax preferences. The empirical results suggest that firms with participation of pension funds and shareholders users of pyramidal structure as control enhancing mechanisms are more and less likely to use ACE system, respectively. Therefore, there may be a "ACE clientele effect" induced by heterogeneity in tax preferences among shareholders.

Policy makers have recognized the effect of the interest tax deductibility on the asymmetric treatment of debt and equity as one the factors that promote the distortion in incentives to leverage (FSB Financial Stability Board, 2015) being intensified in developing countries due to high inflation (Abramovsky, Klemm, \& Phillips, 2014). Indeed, non-financial companies from emerging countries have experienced large increases in their leverage above levels considered normal. This increase in leverage has been recognized as an issue that has implications on economic growth and financial system stability. In response to this situation, policy makers have suggested the adoption of allowance for corporate equity as a way address the debt-equity tax bias in emerging markets (FSB Financial Stability Board, 2015). The implementation of ACE system in emerging economies is more challenging, but it can bring great advances in these economies (Abramovsky et al., 2014). Differences between advanced and emerging economies could lead to different trade-offs between the designs of tax systems (Miller, 2014), so even though Brazil is the only emerging economy with ACE system, it is expected that their experience be a lesson for ACE systems implementations expected in the near future.

The empirical results about the Brazilian experience suggest that the new ACE system designs must address concerns about the effects of eligibility criteria. In Brazil, distribution cash requirement causes negative net benefits to the tax treatment of debt bias. The necessity of distribution of cash makes the ACE systems to compete with the preference of firms to retain internal funds. In addition, the capacity to controlling shareholders in setting the cash distribution policy according to their tax preferences can have two effects: make the effectiveness of the ACE system dependent on the ownership structure and substantially change the ownership patterns of firms by tax-induced clientele effect. Therefore, the underlying mechanism of the Brazilian ACE system is flawed and it needs to be redesigned to fulfill its role. In this reformulation Brazil can follow the current ACE systems of Belgium and Italy that have shown positive results in the treatment of debt tax bias (Panier et al., 2013; Panteghini, Parisi, \& Pighetti, 2012) and do not require the distribution of funds as a criterion for obtaining tax deductibility of equity.

Our empirical results also contribute to the literature on corporate governance, on capital structure and cash distribution policies when considering the way firms react to tax incentives in 
the presence of tax preferences by controlling and influent shareholders, by adjusting their decisions on the level of debt, equity and cash distribution to shareholders.

\section{Acknowledgments}

The authors thank the support of Business Research Unit (BRU-IUL), FCT and the financial support given by CAPES/PDSE (4139-2014-03), CAPES/PROSUP and Mackenzie Research Fund.

\section{References}

Abramovsky, L., Klemm, A., \& Phillips, D. (2014). Corporate Tax in Developing Countries: Current Trends and Design Issues. Fiscal Studies, 35(4), 559-588. http://doi.org/10.1111/j.1475-5890.2014.12042.x

Acharya, V. V., Almeida, H., \& Campello, M. (2007). Is cash negative debt? A hedging perspective on corporate financial policies. Journal of Financial Intermediation, 16(4), 515-554. http://doi.org/10.1016/j.jfi.2007.04.001

Almeida, A. F. F. de, \& Paes, N. L. (2013). The influence of interest on net equity and interest rates on tax neutrality - a case study of the Brazilian corporate taxation. EconomiA, 14(34), 185-198. http://doi.org/10.1016/j.econ.2013.10.004

Almeida, H., \& Campello, M. (2010). Financing Frictions and the Substitution between Internal and External Funds. Journal of Financial and Quantitative Analysis, 45(03), 589-622. http://doi.org/10.1017/S0022109010000177

Almeida, H., Campello, M., \& Weisbach, M. S. (2004). The Cash Flow Sensitivity of Cash. The Journal of Finance, LIX(4), 1777-1804. http://doi.org/10.1111/j.1540-6261.2004.00679.x

Arslan, Ö., Florackis, C., \& Ozkan, A. (2006). The role of cash holdings in reducing investment-cash flow sensitivity: Evidence from a financial crisis period in an emerging market. Emerging Markets Review, 7(4), 320-338.

http://doi.org/10.1016/j.ememar.2006.09.003

Blouin, J., Core, J. E., \& Guay, W. (2010). Have the tax benefits of debt been overestimated? Journal of Financial Economics, 98(2), 195-213. http://doi.org/10.1016/j.jfineco.2010.04.005

Boadway, R., \& Bruce, N. (1984). A general proposition on the design of a neutral business tax. Journal of Public Economics, 24(2), 231-239. http://doi.org/10.1016/00472727(84)90026-4

Bond, S. R., \& Devereux, M. P. (1995). On the design of a neutral business tax under uncertainty. Journal of Public Economics, 58(1), 57-71. http://doi.org/10.1016/00472727(94)01471-Y

Booth, L., Aivazian, V., \& Demirguc-kunt, A. (2001). Capital Structures in Developing Countries. The Journal of Finance, LVI(1), 87-130. 
Boulton, T. J., Braga-Alves, M. V., \& Shastri, K. (2012). Payout policy in Brazil: Dividends versus interest on equity. Journal of Corporate Finance, 18(4), 968-979. http://doi.org/10.1016/j.jcorpfin.2011.09.004

Brasil. Lei n. 7.689, de 15 de Dezembro de 1988. (1988). Institui contribuição social sobre o lucro das pessoas jurídicas e dá outras providências. Retrieved from http://www.receita.fazenda.gov.br/legislacao/leis/ant2001/lei953297.htm

Brasil. Lei n. 9.249, de 26 de Dezembro de 1995. (1995). Altera a legislação do imposto de renda das pessoas jurídicas, bem como da contribuição social sobre o lucro líquido,. Retrieved from http://www.planalto.gov.br/ccivil_03/leis/19249.htm

Brasil. Lei no 9.532, de 10 de dezembro de 1997 (1997). Altera a legislação tributária federal e dá outras providências. Retrieved from http://www.receita.fazenda.gov.br/legislacao/leis/ant2001/lei953297.htm

Brav, A., Graham, J. R., Harvey, C. R., \& Michaely, R. (2008). Managerial Response to the May 2003 Dividend Tax Cut. Financial Management, 37(4), 611-624. http://doi.org/10.1111/j.1755-053X.2008.00027.x

Carvalhal, A., \& Leal, R. P. C. (2013). The world financial crisis and the international financing of Brazilian companies. BAR - Brazilian Administration Review, 10(1), 18-39. http://doi.org/10.1590/S1807-76922012005000007

Cerulli, G. (2014). CTREATREG: Stata module for estimating dose-response models under exogenous and endogenous treatment (No. 5). Retrieved from www.ceris.cnr.it $/$ index.php?option=com_content\&task=section\&id=4\&Itemid=64

Chetty, R., \& Saez, E. (2005). Dividend Taxes and Corporate Behavior: Evidence from the 2003 Dividend Tax Cut. Quarterly Journal of Economics, CXX(August), 791-833. http://doi.org/10.1093/qje/120.3.791

Colombo, J. A., \& Terra, P. R. S. (2014). Payout policy, ownership strucure, taxation, and corporate value: evidence from Brazil. Retrieved from http://www.ufrgs.br/ppge/pcientifica/2014_06.pdf

Costa, C. M., Paz, L. S., \& Funchal, B. (2008). Are Brazilian Firms Savings Sensitive to Cash Windfalls? Brazilian Business Review, 5(2), 136-142. http://doi.org/http://dx.doi.org/10.15728/bbr.2008.5.2.4

Crisóstomo, V. L., López-Iturriaga, F. J., \& Vallelado González, E. (2014). Nonfinancial companies as large shareholders alleviate financial constraints of Brazilian firm. Emerging Markets Review, 18, 62-77. http://doi.org/10.1016/j.ememar.2014.01.005

De Mooij, R. a. (2011). The Tax Elasticity of Corporate Debt: A Synthesis of Size and Variations. IMF Working Papers, 11(95), 1. http://doi.org/10.5089/9781455253340.001

De Mooij, R. A. (2012). Tax Biases to Debt Finance : Assessing the Problem, Finding Solutions. Fiscal Studies, 33(4), 489-512.

De Mooij, R. a., \& Devereux, M. P. (2010). An applied analysis of ACE and CBIT reforms in the EU. International Tax and Public Finance, 18(1), 93-120. http://doi.org/10.1007/s10797-010-9138-8 
De Mooij, R. a., Keen, M., \& Orihara, M. (2013). Taxation, Bank Leverage, and Financial Crises (No. WP/13/48). IMF Working Papers (Vol. 13). Retrieved from http://elibrary.imf.org/view/IMF001/20295-9781475577709/202959781475577709/20295-9781475577709.xml

Desai, M. A., \& Jin, L. (2011). Institutional tax clienteles and payout policy. Journal of Financial Economics, 100(1), 68-84. http://doi.org/10.1016/j.jfineco.2010.10.013

Devereux, M., \& Freeman, H. (1984). A General Neutral Profits Tax. Fiscal Studies, 12(1991), 1-15. http://doi.org/10.1111/j.1475-5890.1991.tb00158.x

Fatica, S., Hemmelgarn, T., \& Nicodème, G. (2012). The Debt-Equity Tax Bias : consequences and solutions (No. 33-2012). Retrieved from http://ec.europa.eu/taxation_customs/resources/documents/taxation/gen_info/economic_an alysis/tax_papers/taxation_paper_33_en.pdf

Fazzari, S. M., Hubbard, R. G., \& Petersen, B. C. (1988). Financing Corporate and Constraints Investment. Brookings Papers on Economic Activity, 1, 141-206.

Frank, M. Z., \& Goyal, V. K. (2009). Capital Structure Decisions: Which Factors Are Reliably Important? Financial Management, 38(1), 1-37. http://doi.org/10.1111/j.1755053X.2009.01026.x

FSB Financial Stability Board. (2015). Corporate Funding Structures and Incentives (Vol. 2015/47). Basel. Retrieved from http://www.financialstabilityboard.org/wpcontent/uploads/Corporate-funding-structures-and-incentives.pdf

Graham, J. R. (2000). How Big Are the Tax Benefits of Debt? The Journal of Finance, LV(5), 1901-1941. http://doi.org/10.1111/0022-1082.00277

Graham, J. R., \& Leary, M. T. (2011). A Review of Empirical Capital Structure Research and Directions for the Future. A Review of Empirical Capital Structure Research, 3(309-345), 309-345. http://doi.org/10.1146/annurev-financial-102710-144821

Harris, M., \& Raviv, A. (1991). The Theory of Capital Structure. The Journal of Finance, XLVI(1), 297-355. http://doi.org/10.1111/j.1540-6261.1991.tb03753.x

Heckman, J. J. (1979). Sample Selection Bias as a Specification Error. Econometrica, 47(1), 153-161. http://doi.org/10.2307/1912352

Hemmelgarn, T., \& Nicodeme, G. (2010). The 2008 financial crisis and taxation policy (No. 2932). Retrieved from http://hdl.handle.net/10419/30738

Hirano, K., \& Imbens, G. W. (2004). The Propensity Score with Continuous Treatments. In A. Gelman \& X.-L. Meng (Eds.), Applied Bayesian Modeling and Causal Inference from Incomplete-Data Perspectives: An Essential Journey with Donald Rubin's Statistical Family. John Wiley \& Sons, Ltd, Chichester, UK. http://doi.org/10.1002/0470090456.ch7

Hubbard, R. G. (1998). Capital-Market Imperfections and Investment. Journal of Economic Literature, 36(1), 193-225.

ICC Commission on Taxation. (2012). Limitations of deductions of interest payments (No. 180520). Retrieved from http://www.iccwbo.org/Advocacy-Codes-and-Rules/Documentcentre/2012/ICC-Policy-Statement-Limitations-of-deductions-of-interest-payments/ 
IFS Capital Taxes Group. (1991). Equity for companies: a corporation tax for the 1990S. London. Retrieved from http://www.ifs.org.uk/comms/comm26.pdf

IMF. (2009). Debt Bias and Other Distortions : Crisis-Related Issues in Tax Policy. Retrieved from https://www.imf.org/external/np/pp/eng/2009/061209.pdf

Keuschnigg, C., \& Dietz, M. D. (2007). A growth oriented dual income tax. International Tax and Public Finance, 14(2), 191-221. http://doi.org/10.1007/s10797-006-8722-4

Khurana, I. K., Martin, X., \& Pereira, R. (2009). Financial Development and the Cash Flow Sensitivity of Cash. Journal of Financial and Quantitative Analysis, 41(04), 787. http://doi.org/10.1017/S0022109000002647

Klemm, A. (2007). Allowances for Corporate Equity in Practice. CESifo Economic Studies, 53(2), 229-262. http://doi.org/10.1093/cesifo/ifm007

Korkeamaki, T., Liljeblom, E., \& Pasternack, D. (2010). Tax reform and payout policy: Do shareholder clienteles or payout policy adjust? Journal of Corporate Finance, 16(4), 572 587. http://doi.org/10.1016/j.jcorpfin.2009.12.003

Meza, D. De, \& Webb, D. C. (1987). Too Much Investment : A Problem of Asymmetric Information. The Quarterly Journal Od Economics, 102(2), 281-292.

Miller, H. (2014). Current Issues in Corporate Tax. Fiscal Studies, 35(4), 397-400. http://doi.org/10.1111/j.1475-5890.2014.12035.x

Miller, M. H., \& Modigliani, F. (1961). Dividend policy, growth, and the Valuation os Shares. The Journal of Business, 34(4), 411-433.

Modigliani, F., \& Miller, M. H. (1958). The Cost of Capital, Corporation Finance and the Theory of Investment. The American Economic Review, 48(3), 261-297.

Morck, R. (2004). How to Eliminate Pyramidal Business Groups - The Double Taxation of Inter-Corporate Dividends and Other Incisive Uses of Tax Policy (No. 10944). Cambridge, MA. Retrieved from http://www.nber.org/papers/w10944

Myers, S. C., \& Majluf, N. S. (1984). Corporate financing and investment decisions when firms have information that investors do not have. Journal of Financial Economics, 13(2), 187221. http://doi.org/10.1016/0304-405X(84)90023-0

Ness Junior, W., \& Zani, J. (2001). Os juros sobre o capital próprio versus a vantagem fiscal do endividamento. Revista de Administração, 36(2), 89-102.

Panier, F., González-Pérez, F., \& Villanueva, P. (2013). Capital Structure and Taxes: What Happens When You (Also) Subsidize Equity? Retrieved from https://www.gsb.stanford.edu/gsb-cmis/gsb-cmis-download-doc/364486

Panteghini, P., Parisi, M. L., \& Pighetti, F. (2012). Italy's ACE tax and its effect on a firm's leverage (No. 3869). Retrieved from http://www.cesifogroup.de/portal/page/portal/DocBase_Content/WP/WP-CESifo_Working_Papers/wpcesifo-2012/wp-cesifo-2012-06/cesifo1_wp3869.pdf

Portal, M. T., Zan, J., \& Silva, C. E. S. da. (2012). Financial frictions and substitution between internal and external funds in publicly traded Brazilian companies. Revista Contabilidade 
\& Finanças, 23(58), 19-32. http://doi.org/10.1590/S1519-70772012000100002

Radulescu, D. M., \& Stimmelmayr, M. (2007). ACE versus CBIT: Which is Better for Investment and Welfare? CESifo Economic Studies, 53(2), 294-328.

http://doi.org/10.1093/cesifo/ifm011

Rosenbaum, P. R., \& Rubin, D. B. (1983). The central role of the propensity score in observational studies for causal effects. Biometrika, 70(1), 41-55.

http://doi.org/10.1093/biomet/70.1.41

Schoenmaker, D., \& Goodhart, C. (2010). Removing tax advantages of debt is vital. Financial Times, pp. 10-11. Retrieved from http://www.ft.com/cms/s/0/0ab3e042-13bb-11e0-814c00144feabdc0.html\#axzz3Hy9JrfIv

Shackelford, D. A., Shaviro, D. N., \& Slemrod, J. (2010). Taxation and the financial sector. National Tax Journal, 63(December), 781-806.

Shaviro, D. (2012). 2008 Financial Crisis : Implications for Income Tax Reform. In J. S. Alworth \& G. Arachi (Eds.), Taxation and the Financial Crisis (pp. 174-189). Oxford University Press. http://doi.org/10.1093/acprof:oso/9780199698165.001.0001

Strebulaev, I. A. (2007). Do Tests of Capital Structure Theory Mean What They Say? The Journal of Finance, LXII(4), 1747-1787. http://doi.org/10.1111/j.1540-6261.2007.01256.x

Vogt, S. C. (1994). The role of internal financial sources in firm financing and investment decisions. Review of Financial Economics, 4(1), 1-24. http://doi.org/10.1016/10583300(94)90002-7

Warren Jr., A. C. (1974). The Corporate Interest Deduction : A Policy Evaluation. The Yale Law Jounal, 83, 1585-1619.

Welch, I. (2004). Capital Structure and Stock Returns. Journal of Political Economy, 112(1), 106-132. http://doi.org/10.1086/379933

Welch, I. (2011). Two Common Problems in Capital Structure Research: The Financial-DebtTo-Asset Ratio and Issuing Activity Versus Leverage Changes. International Review of Finance, 11(1), 1-17. http://doi.org/10.1111/j.1468-2443.2010.01125.x

Zani, J., Leites, E. T., Macagnan, C. B., \& Portal, M. T. (2014). Interest on equity and capital structure in the Brazilian context. International Journal of Managerial Finance, 10(1), 3953. http://doi.org/10.1108/IJMF-08-2011-0068 


\begin{tabular}{|c|c|}
\hline Variables & Definition \\
\hline Financial Debt-to-Assets & Ratio of financial debt to total assets. \\
\hline Financial Debt-to-Capital & $\begin{array}{l}\text { Ratio of financial debt to capital. Capital is defined as equity plus } \\
\text { financial debt. }\end{array}$ \\
\hline IOE & Ratio of interest on equity to total assets. \\
\hline IOE normalized & $\begin{array}{l}\text { Ratio of interest on equity to total assets. (IOE) normalized in order to } \\
\text { only vary between } 0 \text { (inexistence of treatment) and } 100 \text { (maximum } \\
\text { level of observed treatment). }\end{array}$ \\
\hline CAPEX & Ratio of capital expenditures to total assets. \\
\hline Cash flow & Ratio of net income plus depreciation to total assets. \\
\hline Cash holding & Ratio of cash holdings to total assets. \\
\hline Control rights & $\begin{array}{l}\text { Percentage of shares with voting rights owned by the controlling } \\
\text { shareholder. }\end{array}$ \\
\hline Deductible IOE & $\begin{array}{l}\text { Ratio of Deductible IOE to total assets. Deductible IOE is the Product } \\
\text { between the difference of the previous year equity and revaluation } \\
\text { reserves and the long-term interest rate, limited to the highest of } 50 \% \\
\text { of the net income or retained earnings of the previous year. }\end{array}$ \\
\hline Dividend & Ratio of cash dividend to total assets. \\
\hline Dividend normalized & $\begin{array}{l}\text { Ratio of cash dividend to total assets. (Dividend) normalized in order } \\
\text { to only vary between } 0 \text { (inexistence of treatment) and } 100 \text { (maximum } \\
\text { level of observed treatment). }\end{array}$ \\
\hline Dividends dummy & $\begin{array}{l}\text { Dummy variable that takes the value of one if the firm pays dividends } \\
\text { and zero otherwise. }\end{array}$ \\
\hline Financial uncontraint dummy & $\begin{array}{l}\text { Dummy variable that takes a value of one if the firm is not financial } \\
\text { constrained and zero otherwise. Firms with ADR are considered not } \\
\text { financial contrained. }\end{array}$ \\
\hline Firm dummy & $\begin{array}{l}\text { Dummy variable that takes the value of one if the controlling } \\
\text { shareholder is a firm and zero otherwise. }\end{array}$ \\
\hline Funds dummy & $\begin{array}{l}\text { Dummy variable that takes the value of one if an investment fund owns } \\
\text { more than } 5 \% \text { of shares with voting rights and zero otherwise. }\end{array}$ \\
\hline Governance quality dummy & $\begin{array}{l}\text { Dummy variable that takes the value of one if the firm is listed on the } \\
\text { three high-governance listing of BM\&Fbovespa, and zero otherwise. }\end{array}$ \\
\hline Individual dummy & $\begin{array}{l}\text { Dummy variable that takes the value of one if the controlling } \\
\text { shareholder is an individual and zero otherwise. }\end{array}$ \\
\hline IOE dummy & $\begin{array}{l}\text { Dummy variable that takes the value of one if the firm pays interest on } \\
\text { equity and zero otherwise. }\end{array}$ \\
\hline Market-to-book & $\begin{array}{l}\text { Ratio of market value of assets to total assets. The market value of } \\
\text { assets is defined as total assets minus equity plus the market value of } \\
\text { equity. }\end{array}$ \\
\hline Payout ratio & Ratio of cash dividend to net income. \\
\hline Pyramid Control & $\begin{array}{l}\text { Dummy variable that takes the value of one if the ultimate controlling } \\
\text { shareholder uses a pyramid structure and zero otherwise. }\end{array}$ \\
\hline Size & Natural logarithm of total assets. \\
\hline Tax shield & $\begin{array}{l}\text { Ratio of the difference of EBIT and the ratio of income tax payments } \\
\text { to corporate tax rate to sales. }\end{array}$ \\
\hline
\end{tabular}

